\title{
CLASSIFICAÇÃO DOS USOS DE ANTROPÔNIMOS NO PORTUGUÊS ESCRITO ${ }^{1}$
}

\author{
CLASSIFICATION OF USES OF ANTHROPONYMS IN WRITTEN PORTUGUESE
}

\author{
Eduardo Tadeu Roque Amaral \\ Universidade Federal de Minas Gerais
}

\begin{abstract}
Resumo
Este trabalho apresenta uma análise de diferentes usos de antropônimos em textos contemporâneos de língua portuguesa. Com base em recentes pesquisas sobre os nomes próprios, especialmente sobre os chamados nomes próprios modificados (GARYPRIEUR, 1994; 2001; JONASSON, 1994; KLEIBER, 1981; 2005; LANGUE FRANÇAISE, 2005; LEROY, 2004), propõe-se uma classificação de dados do português, coletados em textos do jornal Folha de São Paulo publicados em maio de 2009. Diante dos inconvenientes causados pela distinção entre nomes próprios modificados e nomes próprios não modificados, a questão que orienta o trabalho é: como é possível classificar as diferentes construções com nomes próprios de pessoa? Nesse sentido, tendo por base critérios relativos à referência, são identificados três grupos de interpretações para os sintagmas nominais formados a partir de antropônimos.
\end{abstract}

Palavras-chave: Nomes próprios. Antropônimos. Semântica. Referência.

\begin{abstract}
This study presents an analysis of different uses of anthroponyms in contemporary texts in the Portuguese language. Based on recent research on the proper names, especially on the so called modified proper names (GARY-PRIEUR, 1994; 2001; JONASSON, 1994; KLEIBER, 1981; 2005; LANGUE FRANÇAISE, 2005; LEROY, 2004), we propose a classification of data from the Portuguese, collected from the texts of the newspaper Folha de São Paulo, published in May 2009. Due to the inconvenience caused by the distinction between modified and unmodified proper names, the question that guides this work is: how is it possible to classify the different constructions with people's proper names? Thus, based on criteria related to the reference, three groups of interpretations are identified for the noun phrases formed with anthroponyms.
\end{abstract}

Keywords: Proper names. Anthroponyms. Semantics. Reference.

\section{INTRODUÇÃO}

Os sintagmas nominais destacados abaixo possuem um antropônimo (nome próprio de pessoa) em sua constituição, mas acarretam interpretações diferentes. Se, em (1), o referente do SN corresponde ao portador do nome próprio (o atual presidente dos Estados Unidos), o mesmo não se pode dizer de (2) e (3). Observa-se que, em (2), o referente não corresponde ao escritor João Ubaldo Ribeiro e que em (3) a referência é

\footnotetext{
${ }^{1}$ Apoio: Programa de Auxílio à Pesquisa de Doutores Recém Contratados - PRPq-UFMG.
} 
feita a espaços físicos (rua e rodovia), os quais apenas levam o nome do músico brasileiro Ataulfo Alves de Souza (1909-1969).

(1) No entanto, Restiffe não segue a linha fotojornalista ou documental. A posse de Obama, por exemplo, tem diversas fotografias imperfeitas, com borrões produzidos pela entrada de luz quando fotografava. A multidão muitas vezes é observada de costas e não há retratos expressivos nem detalhes de personagens. E o próprio Obama não é visto.

(http://www1.folha.uol.com.br/fsp/ilustrad/fq1405200908.htm)

(2) Nos dias de hoje, um novo João Ubaldo teria de se atirar das Torres Gêmeas ou de algo parecido para se fazer conhecido. (http://www1.folha.uol.com.br/fsp/ilustrad/fq0405200933.htm)

(3) Miraí tem rua Ataulfo Alves, rodovia Ataulfo Alves (ligação com Cataguases), monumento a ele, um memorial com informações sobre sua vida e, a partir da festa de sábado, terá uma estátua dele na praça central.

(http://www1.folha.uol.com.br/fsp/ilustrad/fq0105200915.htm)

Considerando os distintos referentes dos sintagmas que contêm um nome próprio de pessoa, este trabalho tem o objetivo de propor uma classificação de dados do português, coletados em textos do jornal Folha de São Paulo publicados em maio de 2009. A hipótese é que, observando os aspectos relativos à referência, é possível evitar a separação entre nomes próprios modificados e não modificados usada em trabalhos contemporâneos sobre o tema.

A organização do artigo é a seguinte: na próxima seção, retomam-se alguns aspectos teóricos discutidos por estudos recentes sobre o chamado nome próprio modificado. Na seção posterior, são analisados os dados coletados na versão eletrônica da Folha de São Paulo. Ainda na mesma seção, retoma-se a proposta do artigo, utilizando-se para isso exemplos que contêm o antropônimo do médico e cientista brasileiro Carlos Chagas. Por fim, apresentamos as conclusões obtidas a partir da análise dos dados coletados.

\section{ASPECTOS TEÓRICO-METODOLÓGICOS}

A proposta deste trabalho surge a partir de discussões de recentes pesquisas, especialmente de linguistas franceses, sobre os usos de nomes próprios chamados de modificados - cf. Gary-Prieur (1994; 2001), Jonasson (1994), Kleiber (1981; 2005), Langue Française (2005), Leroy (2004), entre outros.

Para Kleiber (1981), o precursor da análise dos nomes próprios modificados, a distinção entre nome próprio não modificado e nome próprio modificado permitiria dar conta da diferença entre Paul danse e C'est un Paul qu'elle a mis au monde. Além do mais, reafirma Kleiber (1995, p. 12), sua teoria ofereceria uma saída satisfatória ao dilema semiótico relativo ao sentido do nome próprio (cf. FERNÁNDEZ LEBORANS, 1999).

Vários linguistas deram prosseguimento às análises iniciadas por Kleiber (1981) e, mais recentemente, o número 146 da revista Langue Française (2005) também se volta para o tema - seu título é Noms propres: la modification. Os artigos dessa publicação dedicam-se a diferentes estruturas como un + certain + nom propre, même + nom 
propre etc., consideradas como exemplos de usos modificados. Mas Gary-Prieur (2005), que também publica um artigo nesse número da revista, evita o termo modificado, porque esse introduziria, segundo a autora, a ideia de que o nome próprio não é mais verdadeiramente ele mesmo. Além do mais, argumenta Gary-Prieur (2005), a modificação de que tratam os linguistas é ora sintática, ora semântica, ora sintática e semântica e, normalmente, não se diz o que está modificado e como.

Outro problema relacionado ao uso da expressão nome próprio modificado é apresentado por Noailly (2000, p. 22). A autora alega que é curioso que se designem os nomes próprios referenciais (ou ordinários) - que são os mais frequentes na língua - por meio de uma denominação indireta e negativa (não modificado). Por isso, defende que seria mais lógico adotar a sugestão de Flaux (1995, p. 65), segundo a qual se falaria em nomes próprios e empregos derivados dos nomes próprios. A sugestão desta autora também precisaria ser reavaliada, uma vez que ela identifica os empregos derivados aos usos determinados dos nomes próprios, o que, como se verá na análise, não é possível fazer - em nossos dados, vários usos determinados não entrariam em empregos derivados. A crítica de Noailly (2000) foi discutida inclusive por Kleiber (2006, p. 40), mas este mantém o rótulo nome próprio modificado e alega ser difícil adotar um par de denominações que não seja criticável.

Tendo em vista a polêmica gerada a partir da distinção acima citada, neste trabalho, abandonamos o termo modificado e, com base na observação do referente dos sintagmas formados a partir de nomes próprios, distinguimos três grupos de usos antroponímicos. No primeiro grupo, estão as ocorrências em que o referente do SN que contém o antropônimo identifica-se com o portador inicial do nome próprio - este SN pode estar constituído pelo antropônimo nu ou pode estar acompanhado por artigos, possessivos, demonstrativos etc. No segundo, estão os casos em que o referente do SN não se identifica com o portador inicial do nome próprio, mas mantém uma relação com este, a qual pode surgir a partir de propriedades ou produtos (obras) desse portador inicial. No último grupo, o referente do SN não tem nenhuma relação com o indivíduo portador do nome próprio e seria possível inclusive falar em ex-antropônimo.

Antes de passarmos à análise propriamente, convém aclarar algumas noções importantes. Por antropônimo, compreende-se o item lexical que é utilizado pelo usuário da língua para referir-se a um indivíduo do mundo real ou fictício (neste caso, com traços humanos). Esse indivíduo, portador do nome próprio, constitui o referente inicial, em oposição ao referente discursivo do SN antroponímico, que não corresponderá sempre ao portador do nome próprio (JONASSON, 1994). Incluímos entre os antropônimos (sejam prenomes, sobrenomes, apelidos, hipocorísticos, etc.) aqueles que se referem a personagens de obras de ficção, embora a maior parte seja de nomes de pessoas célebres da nossa cultura.

A respeito da metodologia de coleta de dados, para este trabalho, utilizou-se um corpus constituído de textos publicados na seção Ilustrada da Folha de São Paulo, durante o mês de maio de 2009. No decorrer da leitura de tais textos, foram identificadas todas as ocorrências em que o antropônimo se diferenciava do uso chamado de ordinário (ou não modificado): Paulo trabalha nesta empresa. Na análise que se segue, não se apresentam todos os dados coletados, mas os que estão expostos constituem uma amostra bem 
representativa das interpretações possíveis. À medida que forem sendo elencados, outras questões teóricas serão discutidas.

\section{ANÁLISE DOS DADOS}

Durante a análise, expõem-se primeiramente os dados do Grupo 1. Como as ocorrências deste grupo apresentam-se em construções diferentes, serão reunidas por configuração sintática. Em seguida, são expostos os dados que correspondem ao Grupo 2. Nesse caso, também será observada a configuração sintática, embora esta não seja utilizada para a divisão da subseção em itens. Ocorrências do Grupo 3, que não constituem casos autênticos de antropônimos, serão bem menos exemplificadas e não se fará uma discussão mais profunda a respeito. Acreditamos que devem fazer parte de trabalhos com outra perspectiva ${ }^{2}$.

\subsection{Grupo 1}

Neste grupo, encontram-se as ocorrências em que o referente do SN que contém o antropônimo identifica-se com o portador inicial do nome próprio. Inicialmente, incluem-se os usos chamados de referencial ordinário: os antropônimos aparecem sintaticamente nus, como é o caso de Dolores Duran e Dolores em (4), Ramos e Boal em (5):

(4) A morte precoce de Dolores Duran, aos 29 anos, cortou uma carreira de cantora antes que ela atingisse seu ápice. Dolores deixou pouco mais de cem gravações, e a posteridade a consagrou exclusivamente como compositora -o que também se compreende pela força de suas canções.

(http://www1.folha.uol.com.br/fsp/ilustrad/fq0605200913.htm)

(5) Durante a entrevista, [Lázaro] Ramos pergunta a [Augusto] Boal o que ele gostaria de deixar para o mundo: "Meus livros, que escrevo e reescrevo o tempo todo, e o teatro do oprimido", diz.

(http://www1.folha.uol.com.br/fsp/ilustrad/fq1105200912.htm)

Ao observar a constituição interna dos antropônimos com essa interpretação, Amaral (2008) identifica várias ocorrências em língua espanhola nas quais o apelido é inserido entre (ou após) os demais itens antroponímicos, como em Jorge "Cacho" Fontana, Diego "Chavo" Fucks, Gabriel "Chula" Clausi, Juan Maglio "Pacho" e muitos outros. Nos dados de língua portuguesa, não é comum que se encontrem antropônimos nessa forma. Entre os dados coletados, o único exemplo foi o seguinte, em que se tem o nome do personagem russo do filme Os Falsários:

(6) Premiado com o Oscar de filme estrangeiro em 2008, essa reconstituição do episódio se apoia no livro de memórias "Des Teufels Werkstatt" (A oficina do diabo), do eslovaco Adolf Burger, mas adota como protagonista o russo Salomon "Sally" Sorowitsch, livremente inspirado em personagem verídico, Salomon Smolianoff. (http://www1.folha.uol.com.br/fsp/ilustrad/fq2905200919.htm)

\footnotetext{
${ }^{2}$ Com efeito, para os derivados morfológicos de antropônimos, também chamados de deonomásticos (ou, mais especificamente, deantroponímicos) estamos desenvolvendo outra pesquisa.
} 
Além das ocorrências com antropônimo nu, é preciso considerar que, neste grupo com interpretação referencial ordinária, podem-se incluir os casos em que o antropônimo está precedido por itens como artigos, demonstrativos e possessivos, entre outros. Vejamos os exemplos.

\subsubsection{Antropônimos precedidos por artigo definido singular [Art. def. sing. + Antr.]}

No português, assim como em línguas como o espanhol, encontram-se frequentemente, em textos escritos, casos de artigo antes de apelidos. Em ocorrências como (7), o apelido encontra-se em estrutura apositiva, ao contrário do que ocorre em (8) e (9). Em (8), o Rei refere-se ao cantor Roberto Carlos e em (9) o Fenômeno retoma o jogador Ronaldo. Nesses casos, observa-se que a ausência do artigo deixaria a construção agramatical.

(7) "Não sei como tem gente com coragem de meter o malho nele nesta cidade. É despeito!", irrita-se Fernando Bento, 64, o Amora, que também foi grande amigo de Ataulfo, apesar da diferença de idade.

(http://www1.folha.uol.com.br/fsp/ilustrad/fq0105200915.htm)

(8) Subirão ao palco com o Rei, no dia 26, Alcione, Zizi Possi, Ana Carolina, Marília Pêra, Ivete Sangalo, Daniela Mercury, Claudia Leitte, Fernanda Abreu, Luiza Possi, Paula Toller e Hebe Camargo. (http://www1.folha.uol.com.br/fsp/ilustrad/fq0605200915.htm)

(9) O pai de Ronaldo, Nélio Nazário, respeita a decisão do jogador de educar o filho Ronald na Europa. Mas não concorda com a afirmação do Fenômeno de que é melhor que o menino "tenha amiguinhos europeus, sem a malandragem dos amiguinhos brasileiros".

(http://www1.folha.uol.com.br/fsp/ilustrad/fq1905200907.htm)

Entretanto, diferentemente do que se observa em outras línguas, em português também ocorre artigo definido antes de antropônimo formado por prenome e sobrenome, como em (10). Pelo fato de essas ocorrências serem mais comuns em textos de língua oral que em textos de língua escrita, não são frequentes no corpus coletado da Folha de São Paulo.

(10) Sem contar que, depois de um dia cheio de laboratórios, debates, há os jantares. Vejo que um deles se chama "produtos brasileiros com tradução argentina". É a Paola Carosella, simples, refinada, gostosa! (http://www1.folha.uol.com.br/fsp/ilustrad/fq2805200919.htm)

\subsubsection{Antropônimos precedidos por artigo definido plural [Art. def. pl. + Antr.]}

Neste subgrupo, identificam-se primeiramente as ocorrências, como em (11), nas quais os indivíduos portadores do nome próprio podem ser individualizados, ou seja, identificados pelas informações contextuais (ou cotextuais). No exemplo seguinte, os 
Jonas refere-se aos irmãos Nick Jonas, Joe Jonas e Kevin Jonas, integrantes da banda Jonas Brothers ${ }^{3}$.

(11) Em apresentação ontem no estádio do Morumbi, para 45 mil pessoas, os Jonas fizeram tudo igualzinho ao DVD

[...]

Apresentando-se pela segunda vez no Brasil (o show no Rio foi no sábado), os irmãos Nick, 17, Joe, 19, e Kevin Jonas, 21, fizeram uma apresentação correta e animada, mas idêntica à da noite anterior e a de outros shows na América do Sul. (http://www1.folha.uol.com.br/fsp/ilustrad/fq2505200934.htm)

Deve-se levar em conta, no entanto, que a mesma construção é utilizada para situações em que não é possível identificar os membros portadores do nome. Nesse caso, a referência do SN antroponímico corresponde à família, o que afastaria esses casos da inclusão neste Grupo 1 - cf. a seção $2.3^{4}$ :

(12) "Os barões do tempo da escravidão passaram a coronéis, o preconceito foi amansando, mas um ranço racista continuou existindo", diz o historiador Luizito Pereira, 64.

Amigo e biógrafo de Ataulfo, Pereira é integrante da família mais tradicional de Miraí, os Alves Pereira, em cuja fazenda Cachoeira o sambista nasceu e trabalhou -o seu Alves veio da rica família.

(http://www1.folha.uol.com.br/fsp/ilustrad/fq0105200915.htm)

Ao contrário do que acontece em outras línguas, em português encontram-se ocorrências de sobrenome com marca de plural, como é o caso de (13) e (14). Esse fato permite levantar a hipótese da necessidade de distinção entre prenomes e sobrenomes na análise morfológica do plural do SN antroponímico. Esse tema, contudo, não será desenvolvido neste trabalho. ${ }^{5}$

(13) Os principais executivos da Globo passaram as últimas quinta e sexta confinados em uma fazenda no interior de Minas Gerais, pertencente a um dos Marinhos. Foram discutir o futuro dos negócios das Organizações Globo.

(http://www1.folha.uol.com.br/fsp/ilustrad/fq3105200904.htm)

\footnotetext{
${ }^{3}$ A ocorrência de os Jonas, em (11), também poderia ser interpretada como referência ao nome do grupo musical. Nesse caso, não teríamos mais um antropônimo, tal como definido inicialmente.

Outro exemplo que pode gerar ambiguidade é o seguinte, em que Sheilas pode se referir às dançarinas de axé Sheila Mello e Sheila Carvalho, mas também pode ter interpretação metafórica: mulheres com propriedades das Sheilas. Neste último caso, não poderia entrar para este Grupo 1.

(i) Não danço axé, não ouço axé, mas transaria com qualquer uma das Sheilas.

(http://www1.folha.uol.com.br/fsp/ilustrad/fq0205200921.htm)

${ }^{4}$ Na verdade, a questão é mais complexa. O uso de [Art. def. pl. + X], em que X é um antropônimo, pode implicar a leitura de que $\mathrm{X}$ corresponde: a) à família $\mathrm{X}$, ou seja, à totalidade dos membros de uma família; b) ao marido, à esposa e filhos; ou c) a dois ou mais membros de uma família identificados contextualmente (cf. GARY-PRIEUR, 2001, p. 46).

${ }^{5}$ Além do mais, no corpus coletado, não se encontrou nenhuma ocorrência com antropônimos precedidos por numerais que pudesse entrar neste grupo. Mas seria perfeitamente possível uma construção com numeral. Veja o caso abaixo para o espanhol, em que a referência é feita a Hernán Melo y Fermín Merlo:
}

(i) Dos Merlo con Jodos. El pianista Ernesto Jodos se presentará con Hernán y Fermín Merlo en contrabajo y batería, respectivamente, mañana, a las 21, en el Banfield Teatro Ensamble, Larrea 350, Lomas de Zamora (http://www.lanacion.com.ar/719716) (AMARAL, 2008, p. 121). 
(14) A ação do "Simplicissimus" está situada na Guerra dos 30 Anos (16181648), na qual se jogava a limitação do poder dos Habsburgos, o destino do Sacro Império e o ajuste dos interesses dos senhorios alemães à sorte da luta entre católicos, luteranos e calvinistas. (http://www1.folha.uol.com.br/fsp/ilustrad/fq3005200912.htm)

3.1.3 Antropônimos precedidos por nome comum, especialmente de parentesco [Art. def. pl. + nome de parentesco + Antr.]

Para identificar determinados membros de uma família, são utilizadas construções como (15) e (16), em que o item irmãos precede o antropônimo. Os indivíduos portadores podem ser dois ou mais: os irmãos Gallagher refere-se a Liam Gallagher e Noel Gallagher, fundadores da banda Oasis, e os irmãos Marx refere-se aos comediantes Leonard Marx, Adolf Arthur Marx, Julius Marx, Milton Marx e Herbert Marx, que fizeram sucesso na primeira metade do século XX.

(15) Durante todo o show do Oasis, uma bandeira inglesa aparecia na plateia. Era de Patrick Caniche, 23, que "ama" a banda e queria homenagear os irmãos Gallagher.

(http://www1.folha.uol.com.br/fsp/ilustrad/fq1105200911.htm)

(16) Um compêndio de clássicos que se preze não poderia dispensar pelo menos um filme dos irmãos Marx -ainda que a palavra "clássico" não combine muito com o estilo anárquico dos humoristas.

(http://www1.folha.uol.com.br/fsp/ilustrad/fq1005200918.htm)

Obviamente, poderíamos encontrar outros nomes de parentesco (tios, avós...) ou outros nomes comuns, mas parece ser recorrente o uso de irmão(s)/a(s) antes de nome próprio para remissão a indivíduos portadores de mesmo antropônimo.

\subsubsection{Antropônimos precedidos por próprio [o/a própio/a + Antr.]}

Há várias ocorrências com próprio, a maioria em contextos em que se retoma o referente portador do nome próprio, como (17):

(17) No entanto, Restiffe não segue a linha fotojornalista ou documental. A posse de Obama, por exemplo, tem diversas fotografias imperfeitas, com borrões produzidos pela entrada de luz quando fotografava. A multidão muitas vezes é observada de costas e não há retratos expressivos nem detalhes de personagens. E o próprio Obama não é visto.

(http://www1.folha.uol.com.br/fsp/ilustrad/fq1405200908.htm)

A análise de próprio pode ser relacionada à de mismo feita por Amaral (2008, p. 126) ${ }^{6}$. É possível afirmar que a função de o/a próprio/a é marcar a retomada anafórica de um referente já mencionado, para poder predicar desse referente algo que não era esperado

6 Destaque-se que não foi encontrada, no corpus para este trabalho, nenhuma ocorrência com antropônimo precedido por mesmo/a, o que não significa, obviamente, que não possa ocorrer - cf. Amaral (2008, p. 122), que identifica e analisa construções como: el mismo León Gieco e el mismísimo Zajac. 
pelo leitor. Assim, no exemplo, esperava-se que Obama fosse visto nas fotos de Mauro Restiffe, mas se explica que ele mesmo, ou seja, o próprio Obama, não é visto.

\subsubsection{Antropônimos precedidos por adjetivo [Art. def. + Adj. + Antr.]}

Nos casos abaixo, inquieta e abstêmio são adjetivos descritivos que não criam a pressuposição de um referente integrante de um contraste. Em (18), inquieta apenas caracteriza Carla Pernambuco, da mesma forma que abstêmio o faz para Hitler em (19). Não se cria a pressuposição de um aspecto não inquieto de Carla, nem de um aspecto não abstêmio de Hitler, como seria possível se os adjetivos estivessem pospostos: $a$ Carla Pernambuco inquieta; o Hitler abstêmio - cf. a seção 3.2.1:

(18) E a inquieta Carla Pernambuco vai nos mostrar as semelhanças de nossa comida com a do Peru. Esse Peru está cheio de segredos, dos quais nem suspeitamos, só conhecemos aquelas batatas enrugadas. (http://www1.folha.uol.com.br/fsp/ilustrad/fq2805200919.htm)

(19) Churchill foi dormir tranquilo, Stálin desconfiou de uma armação para envolvê-lo na guerra do Pacífico e o abstêmio Hitler tomou uma taça de champanhe. (http://www1.folha.uol.com.br/fsp/ilustrad/fq0205200910.htm)

\subsubsection{Antropônimos precedidos por possessivo [(Art. def. +) Pos. + Antr.]}

Os casos de possessivo diante de antropônimos deste grupo representam ocorrências em que o possessivo não é utilizado para restringir a extensão semântica do nome próprio (cf. FERNÁNDEZ LEBORANS, 1999, p. 123). Em (20), o possessivo nosso marca uma relação de identificação de nacionalidade entre o portador inicial do nome próprio e o locutor. O segundo exemplo registra uma tendência de ocorrência de possessivo antes de personagem fictício (cf. AMARAL, 2008, p. 136). Embora em alguns casos seja possível postular uma classe virtual de interpretações feitas por distintos atores, não parece ser esse o caso de (21): o possessivo tende a marcar uma relação do tipo ator/personagem, muito mais que criar uma classe virtual de portadores do antropônimo Caco Antibes.

(20) Tanto o poeta francês Paul Valéry quanto o nosso João Cabral de Melo Neto, que costumava citar o primeiro, desconfiavam de que tudo o que lhes chegasse espontaneamente, à maneira de inspiração, era eco de alguma coisa que houvessem lido, ouvido ou percebido de alguma maneira. (http://www1.folha.uol.com.br/fsp/ilustrad/fq1605200918.htm)

(21) Em sólida parceria com Maria Carmem Barbosa, o autor e comediante Miguel Falabella retoma, com habilidade, todos os recursos da comédia popular, em que o roteiro é pretexto para que os comediantes criem as mais abusadas maneiras de arrancar gargalhadas.

Trash como um Zé do Caixão e ingênuo como um Didi Mocó, seu humor não prima pelo acabamento cênico. A força de seu Caco Antibes, de "Sai de Baixo", fez uma marolinha midiática que tomou o personagem pelo ator.

(http://www1.folha.uol.com.br/fsp/ilustrad/fq1605200914.htm) 


\subsubsection{Antropônimos precedidos por demonstrativo [Dem. + Antr. $]^{7}$}

Fernández Leborans (1999, p. 120) expõe e discute as várias construções e interpretações possíveis do nome próprio precedido por demonstrativo, como aquelas em que há um uso anafórico (endofórico) e outras em que o demonstrativo possui valor dêitico. A autora comenta as dificuldades dos autores em explicar o valor do nome próprio nesses contextos. No corpus para este trabalho, a ocorrência de antropônimo antecedido por demonstrativo foi muito pequena (apenas 2 casos) e não será retomada a discussão proposta pelos autores.

O exemplo abaixo apresenta a construção em que o demonstrativo possui valor dêitico. Com base em Fernández Leborans (1999, p. 122), a qual se baseia em Kleiber (1991), podemos afirmar que o demonstrativo é utilizado para indicar uma qualificação inferível da situação momentânea da enunciação. No exemplo (22), nota-se que essa não distingue dois portadores do nome Maisa, ou, em termos de Gary-Prieur (1994, p. 214), não possui função identificadora, mas se une à caracterização de Maisa como muito engraçada, criança que "não tem mais jeito".

(22) SS [Silvio Santos] tripudia: "Ela é muito engraçada!"; "Essa Maisa não tem mais jeito", enquanto a menina grita histérica ("Não quero!!"), sai correndo do palco. (http://www1.folha.uol.com.br/fsp/ilustrad/fq1705200920.htm)

\subsubsection{Antropônimos precedidos por tal e certo [Art. indef. + tal/certo + Antr.]}

A ocorrência com tal no corpus coletado permite afirmar que o usuário da língua utiliza a construção para não dar destaque ao indivíduo portador do nome próprio. No exemplo (23), Leno usa um tal Paulo para mostrar que o portador do antropônimo Paulo Coelho não possuía, no momento em que leu seu artigo ou o indicou ao amigo Raul Seixas, a mesma importância que teria posteriormente. Como se vê, não se trata de afirmar que o nomeado é desconhecido do falante, conforme expõe Martínez (1999, p. 2727).

(23) Leno conta que foi no Rio, em 1968. "Éramos nordestinos, míopes e magricelas, interessados em astronomia e filosofia." Logo Walter introduz o tema Coelho. Leno conta sua versão sobre o mago e o maluco. Leu na revista "A Pomba" um artigo sobre ufologia de um tal Paulo, que indicou para Raul. (http://www1.folha.uol.com.br/fsp/ilustrad/fq1005200907.htm)

A respeito da construção [Art. + certo + Antr.], registramos o exemplo (24). Nesse caso, a interpretação é semelhante à de um tal Paulo do exemplo acima. Note-se que seria possível substituir certo por tal: um tal Daniel.

(24) FOI NO ÚLTIMO domingo, dia em que Maisa, em vez de descansar do seu sábado tão animado, contracena com Silvio Santos. Ela chama o patrão de lado e tenta fazer um pedido. Ele replica: "Você está com medo?"; "Alguém te bateu?". Ela fica paralisada, faz bico, começa a chorar. SS, então, chama um menino, pouca coisa maior do que a "pequena petiz". O menino, um certo Daniel, está

\footnotetext{
${ }^{7}$ Nesta subseção, consideramos como demonstrativos os itens este, esse, aquele e suas variações. Certos itens que outros autores incluem na classe dos demonstrativos como próprio, mesmo e tal (cf. CASTILHO, 2008, p.117), estão comentados em outras subseções (cf. 3.1.4 e 3.1.8).
} 
com uma maquiagem de "monstro", assustadora -pelo menos para Maisa, que sai correndo, apavorada.

(http://www1.folha.uol.com.br/fsp/ilustrad/fq1705200920.htm)

Sintaticamente, tal e certo possuem diferenças. Em (24), tal poderia vir acompanhado de preposição (um tal de Daniel), o que não é possível com certo (*um certo de Daniel).

\subsection{Grupo 2}

Conforme apontado no início deste trabalho, no segundo grupo identificado encontramse os usos em que o referente do SN não corresponde ao portador inicial do nome próprio. Entretanto, existe uma relação entre o referente e o antropônimo, a qual pode surgir a partir de uma propriedade ou de um produto do portador do nome próprio. Alguns critérios semânticos possibilitam ainda observar uma subdivisão dos casos deste grupo, conforme expostos a seguir.

\subsubsection{A interpretação “manifestação”, “fase” ou “imagem” do referente}

Os casos incluídos neste subgrupo enquadram-se no que Jonasson (1994) chama de interpretação do tipo manifestação, Fernández Leborans (1999) classifica como interpretação relativa a uma fase do referente e Gary-Prieur (2001) denomina interpretação-imagem ${ }^{8}$.

Para Kleiber (2006, p. 41), este uso permitiria remeter às diferentes instâncias espaçotemporais (instances spatio-temporelles) de um indivíduo, uma vez que, segundo o autor, do ponto de vista linguístico, elas não poderiam ser denominadas por um nome próprio. É interessante notar que a língua dispõe de nomes próprios para o indivíduo inteiro e não para suas facetas, as quais necessitam de diferentes construções linguísticas para serem explicitadas. Vejam-se os casos com a construção [Art. + Antr. + expansão].

Em (25), o constituinte destacado se refere a uma faceta do portador do nome próprio, o cantor brasileiro Wilson Simonal, em um espaço temporal específico, a década de sessenta. O mesmo acontece com o Simonal pós-1975, que destaca outro período do mesmo cantor. Obviamente, o indivíduo é o mesmo e a referência é feita a seus diferentes aspectos (fases ou imagens). Essa distinção torna-se clara quando se observa, no exemplo (26), que o autor retoma separadamente os distintos referentes. Em (27), não se trataria mais de fases (no sentido temporal stricto sensu), mas de imagens do cineasta Francis Ford Coppola criadas a partir de suas obras.

(25) De um lado, imagens de arquivo e depoimentos de amigos constroem o Simonal pop da década de 60. Talentoso e carismático, tinha seu próprio programa na TV e domínio absoluto sobre quem parasse para ouvi-lo cantar. (...)

Do outro, nos é montado o Simonal pós-1975. Apagado da história. Magoado, deprimido, alcoólatra, quase sem voz. (...)

(http://www1.folha.uol.com.br/fsp/ilustrad/fq1505200918.htm)

\footnotetext{
${ }^{8}$ Também se encontra entre os autores o termo fracionamento (fractionnement).
} 
(26) Não por acaso, muitos de seus cerca de 85 minutos enfocam esse ponto de virada, quando o primeiro Simonal comete o erro fatal que o transforma no segundo. (http://www1.folha.uol.com.br/fsp/ilustrad/fq1505200918.htm)

(27) Não acho que "Tetro" seja inacessível. Ele [Coppola] é magnífico na forma. Obviamente não é o Coppola de "Apocalipse Now" ou [o Coppola de] "O Poderoso Chefão". Ele é desses cineastas, como foi Kubrick, de quem esperamos sempre algo diferente do que estão dispostos a fazer. (http://www1.folha.uol.com.br/fsp/ilustrad/fq1305200910.htm)

Nos exemplos acima, identificam-se os espaços mentais espaço-tempo e espaço-obra, (cf. AMARAL, 2008; FERNÁNDEZ LEBORANS, 1999; GARY-PRIEUR, 19949). Mas, no caso abaixo, observa-se um novo espaço mental, que poderia ser chamado espaço-ação e identificaria imagens do jogador de basquete Kobe Bryant.

(28) Mas a estrela do adversário, no filme, é Bruce Bowen: o cara cuja função é marcar Kobe. O Kobe grande arremessador todos conhecem. O [Kobe] organizador do time, menos. $\mathbf{O}$ [Kobe] quase técnico, que fala todo o tempo, dá instruções, menos. O sujeito que se diverte jogando (isso se sente em mais ou menos todos os jogadores), que se dedica à chamada "trash talking", é coisa que só um documentário como esse poderia registrar. De resto, Kobe comenta o jogo. A série começa em grande estilo. (http://www1.folha.uol.com.br/fsp/ilustrad/fq3005200918.htm)

Além dos exemplos acima, o corpus também revela exemplos com o artigo indefinido [Art. Indef. + Antr. + expansão]. Observe-se que em (29) ainda é possível falar em manifestação (ou imagem) de Luana Piovani.

(29) "A Mulher Invisível" pega carona no sucesso de "Se Eu Fosse Você 2" e "Divã' Produção tem elenco encabeçado pelo "bom de bilheteria" Selton Mello e por uma Luana Piovani de figurinos exíguos

(http://www1.folha.uol.com.br/fsp/ilustrad/fq3105200913.htm)

Tanto Noailly (1991, p. 104) quanto Jonasson (1994, p. 45) discutem os efeitos semânticos da anteposição a nomes próprios de certos itens, entre os quais estão melhor, pior, verdadeiro, outro, novo, jovem e velho. Em (30), jovem contribui para uma leitura restritiva. Parece haver um contraste entre estágios temporais do referente: jovem/velho, na medida em que o adjetivo remete ao período de vida do escritor (entre seus 23 e 34 anos) correspondente ao período de que trata o livro citado no texto. Nesse sentido, este exemplo, embora tenha uma configuração sintática diferente dos anteriores, apresenta interpretação semelhante ${ }^{10}$.

(30) Para além do voyeurismo, reunião de cartas do jovem Samuel Beckett conta história de formação estética

\footnotetext{
${ }^{9}$ A proposta das autoras baseia-se em Fauconnier (1984).

${ }^{10}$ Por outro lado, é preciso levar em conta que itens como jovem e velho (e suas variações) também podem gerar interpretações como nome (substantivo), a exemplo de (i). Nesse caso, a construção não integra este grupo:

(i) Em "Up", o potencial de risadas e lágrimas deriva da história do velhinho Carl que, viúvo, decide empreender a aventura com que ele e a mulher sonharam desde a infância -explorar a natureza na América do Sul. (http://www1.folha.uol.com.br/fsp/ilustrad/fq1405200914.htm)
} 
A REPERCUSSÃO da recém-publicada correspondência do jovem Beckett, selecionada e anotada por Martha Fehsenfeld e Lois Overbeck (o primeiro de quatro volumes previstos), vai além do voyeurismo biográfico, ainda que, mesmo neste aspecto, o que ela ofereça seja mais do que glacê para tolos.

(http://www1.folha.uol.com.br/fsp/ilustrad/fq0905200914.htm)

Retomando Kleiber (2006), é possível justificar a existência de usos como os desta subseção pelo fato de o indivíduo ser conhecido como uma entidade que permanece a mesma através de suas diferentes instâncias espaço-temporais.

Antes de passar para a próxima subseção, vale a pena comentar o exemplo abaixo. A estrutura é a mesma de (29) [Art. Indef. + Antr. + expansão], mas os referentes não correspondem nem ao portador do nome próprio, nem a uma fase ou aspecto dele, mas a uma produção sua (uma canção). Esse fato é comprovado, sintaticamente, pela coordenação dos SNs sambas, modas de viola e os dois primeiros destacados (um Noel pouco conhecido e um Chico muito gravado) e, semanticamente, pela qualificação de pouco conhecido ou muito gravado atribuída não aos portadores do antropônimo, mas às canções Estátua da Paciência e Samba do Grande Amor. Obviamente, esse exemplo enquadra-se junto aos casos de interpretação metonímica (cf. seção 3.2.3), mas está citado aqui para que se possa observar o contraste com os exemplos acima.

(31) Com seu registro agudo, a cearense Lúcia Menezes atira para vários lados: sambas ("Uva de Caminhão") e modas de viola ("Os Grilos São Astros", "Viola Cantadora"), um Noel pouco conhecido ("Estátua da Paciência") e um Chico muito gravado ("Samba do Grande Amor"), mas predomina o acento nordestino, como nas faixas dos conterrâneos Ednardo ("Terral") e Belchior ("Os Profissionais"), além de um Luiz Gonzaga falando do Rio ("Mangaratiba"). (http://www1.folha.uol.com.br/fsp/ilustrad/fq0605200911.htm)

\subsubsection{A interpretação metafórica}

No corpus da Folha de São Paulo, há várias ocorrências de uso metafórico do antropônimo. Por questão de espaço, foram selecionadas apenas algumas e estão organizadas por configuração sintática. A seleção se deu com o objetivo de expor interpretações diferentes.

No uso metafórico, o SN designa o que Jonasson (1994) chama de referente discursivo. Neste trabalho, conforme exposto no início, adotam-se as noções de referente inicial e de referente discursivo, que serão úteis para a análise dos próximos exemplos.

A construção mais frequente [Art. indef. + Antr. + expansão] foi identificada em exemplos do corpus coletado, como (32). Nessa ocorrência, o referente discursivo identifica-se com um personagem da telenovela Mutantes - Promessas de Amor, mas o SN apositivo está construído com o nome de outro personagem fictício, Shrek, um ogro. Observa-se aqui que a expansão do mal tem a função de denotar um contraste entre as imagens dos referentes inicial e discursivo: opõe-se um referente inicial do bem (Shrek) a um referente discursivo do mal (o mutante Ogro). Destaque-se também que as características introduzidas pela expansão posposta ao antropônimo não são nunca do referente inicial. 
(32) Na tentativa de alavancar "Os Mutantes - Promessas de Amor", da Record, o autor Tiago Santiago voltou a criar mutantes em série. A nova safra terá Rana, a mulher-perereca, que nocauteia com golpes de língua. Mimético terá o poder de se confundir com o cenário. E da computação gráfica sairá Ogro, um Shrek do mal.

(http://www1.folha.uol.com.br/fsp/ilustrad/fq1705200904.htm)

A próxima construção [Art. def. + Antr. + expansão] nos leva à noção de analogia de Gary-Prieur (1994, p. 117), para quem essa noção não se apoiaria sobre uma formulação explícita das propriedades que a fundamentam. De fato, no exemplo abaixo, formula-se uma analogia entre o jogador Ronaldo e o personagem Shrek. A interpretação depende do conhecimento de quais propriedades do referente inicial serão relevantes: observa-se que o jogo de palavras Ronaldo > Gornaldo e Fenômeno > Gordômeno apontam para a propriedade de ser gordo. Note-se a diferença que existe com a comparação feita por meio de o porquinho da gripe, a qual não utiliza um nome próprio, mas sim um nome comum (porquinho), que não identifica um indivíduo único.

(33) E o Gornaldo? Viva o Gordômeno! O Shrek do Timão! Ele tá parecendo o porquinho da gripe.

(http://www1.folha.uol.com.br/fsp/ilustrad/fq0505200903.htm)

A construção [Art. indef. + Antr.] neste subgrupo permite a paráfrase "um indivíduo X com as propriedades do portador inicial do antropônimo”. No caso de (34), Renata Sorrah afirma que Augusto Boal foi, durante o tempo em que viveu, "um indivíduo com as propriedades de Dom Quixote”. O leitor precisa verificar qual é o conteúdo (cf. seção 3.2.4) do portador inicial que seria relevante para a metáfora.

(34) RENATA SORRAH, atriz

"Ele [Augusto Boal] foi um Dom Quixote na vida."

(http://www1.folha.uol.com.br/fsp/ilustrad/fq0405200930.htm)

Interpretação semelhante poderia ser apontada para o exemplo (35), que possui a construção [Art. Indef. + Adj. + Antr.]. Nesse caso, entretanto, o referente discursivo é hipotético.

(35) Para o espanhol Juan Cruz, do "El País", editores têm medo de se arriscar e reverenciam sempre os mesmos nomes

"Nos dias de hoje, um novo João Ubaldo teria de se atirar das Torres Gêmeas ou de algo parecido para se fazer conhecido."

(http://www1.folha.uol.com.br/fsp/ilustrad/fq0405200933.htm)

Outro caso de interpretação metafórica é o de (36), em que o antropônimo é precedido por tanto [tanto + Antr.]. No exemplo abaixo, o referente discursivo, membros de CPIs, recebe a propriedade “ter cabelo tingido” do referente inicial Nelson Rubens.

(36) Avalanche de cabelo tingido. CPI é o Catálogo da Loreal! Nunca vi tanto Nelson Rubens junto!

(http://www1.folha.uol.com.br/fsp/ilustrad/fq2705200903.htm)

Mais uma construção metafórica encontrada no corpus da Folha de São Paulo é a seguinte, em que se unem antropônimos de indivíduos diferentes. Diferentemente dos 
casos anteriores, em que a metáfora é construída a partir de construções sintáticas externas à forma do antropônimo, em (37), há uma mudança na constituição interna do nome próprio:

\section{(37) ENTREVISTA FERNANDA MONTENEGRO}

\section{Fernanda de Beauvoir}

$[\ldots]$

Quem a vê em cena, no monólogo "Viver sem Tempos Mortos", na pele da portavoz do feminismo, Simone de Beauvoir (1908-1986), e depois conversa com ela "à paisana" sobre a peça que estreia em São Paulo nesta quinta entende perfeitamente a descrição. Sob o sol forte da tarde de outono, há em Fernanda um rastro palpável da filósofa francesa.

(http://www1.folha.uol.com.br/fsp/ilustrad/fq1705200912.htm)

Seria possível criar relações metafóricas entre Fernanda Montenegro e Simone de Beauvoir por meio de construções como "uma (nova) Simone de Beauvoir", "nossa Simone de Beauvoir", "a Simone de Beauvoir do teatro / do Brasil”, mas o autor do texto, ao usar Fernanda de Beauvoir rompe um limite formal criado pelo nome próprio, o que produz o efeito de mostrar, no antropônimo, a presença de propriedades da portadora inicial (Simone de Beauvoir) que nem o adjetivo palpável do parágrafo acima conseguiria expressar tão bem.

\subsubsection{A interpretação metonímica}

Nos exemplos deste subgrupo, o referente do SN que contém o antropônimo não é constituído por um (ou mais) indivíduo(s), mas por obras produzidas pelos portadores do nome próprio.

(38) Giornetti, 37, estudou literatura espanhola em Florença. Enquanto lia Cervantes e Lorca, começou a se interessar pela história das roupas. (http://www1.folha.uol.com.br/fsp/ilustrad/fq0105200913.htm)

(39) E o sonho de 50 anos de fazer alguma coisa da Clarice Lispector. Mas sempre tem tantas Clarices sendo feitas que deixo para daqui a pouco. (http://www1.folha.uol.com.br/fsp/ilustrad/fq1705200914.htm)

Esses exemplos constroem-se a partir da notoriedade do portador inicial que o enunciador supõe que o seu leitor possua. Podem ser parafraseados pela construção $a$ obra (o livro, a música, etc.) de: lia a obra de Cervantes, tantas obras de Clarice, etc. Esses argumentos justificam a possibilidade de se construir outro nome próprio (título de espetáculo: Elas cantam Roberto Carlos) com base nessa relação metonímica, como se observa no exemplo abaixo:

(40) O show "Elas Cantam Roberto Carlos" será às 21h, dia 26 de maio, no Teatro Municipal de São Paulo. (http://www1.folha.uol.com.br/fsp/ilustrad/fq0605200915.htm)

\subsubsection{O antropônimo como qualificativo}


A noção de antropônimo como adjetivo qualificativo está baseada na ideia de conteúdo de Gary-Prieur (1994, p. 51), para quem “o conteúdo de um nome próprio é um conjunto de propriedades atribuídas ao referente inicial desse nome próprio em um universo de crença”. Tais propriedades, complementa Gary-Prieur (2001, p. 78), não se encontram no léxico - pois para a autora o nome próprio não tem sentido conceitual -, mas surgem da experiência associada pelos locutores com o referente do nome próprio. No exemplo abaixo, é preciso atribuir a sentido uma propriedade selecionada do portador do nome em destaque, o monstro de origem japonesa Godzilla. Neste caso, trata-se da sua característica de ser grandioso $^{11}$.

(41) Numa ilha, cientista estuda efeitos de terremotos sobre a região. Logo, descobrirá que esses efeitos são grandiosos, no sentido Godzilla da palavra.

(http://www1.folha.uol.com.br/fsp/ilustrad/fq2205200902.htm)

\subsection{Grupo 3}

Neste grupo, encontram-se os casos em que o referente do SN que contém o exantropônimo não se identifica com o indivíduo portador do nome próprio. Os exemplos também são heterogêneos. Primeiramente, podem-se incluir aqueles em que o antropônimo nomeia uma família, como (42). Em segundo lugar, incluem-se aqueles que nomeiam produções culturais ou espaços físicos, como (43) e (44). Em (43), a referência é feita ao prêmio de arquitetura criado por Jay A. Pritzker e em (44) a lugares como rua e rodovia.

(42) Minha filha estreou a ida para Illinois, numa cidadezinha mínima, que nem no mapa aparecia, e foi visitar a família Neher.

(http://www1.folha.uol.com.br/fsp/ilustrad/fq0705200914.htm)

(43) Em permanente tensão entre ser arte ou instrumento de mudança social, a arquitetura celebrou ontem seus princípios básicos, com a entrega do prêmio Pritzker, o Nobel da área, ao suíço Peter Zumthor, 66. (http://www1.folha.uol.com.br/fsp/ilustrad/fq3005200924.htm)

(44) Miraí tem rua Ataulfo Alves, rodovia Ataulfo Alves (ligação com Cataguases), monumento a ele, um memorial com informações sobre sua vida e, a partir da festa de sábado, terá uma estátua dele na praça central. (http://www1.folha.uol.com.br/fsp/ilustrad/fq0105200915.htm)

Por fim, chega-se aos epônimos (nomes comuns originários de nomes próprios), que são objeto de pesquisa de lexicólogos e bastante conhecidos nos estudos das ciências da saúde (MELHEM, 1996). Muitos desses itens eponímicos já são dicionarizados.

(45) Queria ser farmacêutica, não imagino o porquê, mas se deu otimamente ensinando crianças com síndrome de Down e doenças mentais. (http://www1.folha.uol.com.br/fsp/ilustrad/fq1405200921.htm)

\footnotetext{
${ }^{11} \mathrm{O}$ mesmo processo permite que se utilize o antropônimo com a construção [à la Antr.], muito produtiva na língua francesa e também encontrada em português:

(i) Intervenções gráficas pop e uma trilha musical que vai de Ennio Morricone a David Bowie também comparecem, fazendo de "Bastardos Inglórios" um filme de guerra à la Tarantino. (http://www1.folha.uol.com.br/fsp/ilustrad/fq2105200924.htm)
} 
Em todos os casos deste grupo, embora tenha havido uma motivação na aplicação dos antropônimos aos referentes, não existe, nessas ocorrências, relação estrita entre o referente do SN e o portador do antropônimo. O falante pode interpretar sentenças como (43) e (44), por exemplo, sem qualquer conhecimento do portador dos nomes Pritzker ou Ataulfo Alves.

\subsection{Uma visão geral das interpretações dos SNs formados por antropônimos}

Nesta última parte deste trabalho, retomamos as diferentes interpretações que foram vistas nas subseções anteriores e verificaremos sua aplicação com sintagmas formados a partir de um único antropônimo. Como não se encontrou nos dados um mesmo antropônimo com todas as interpretações expostas acima, partiremos do exemplo abaixo, retirado do corpus analisado, para demonstrar as distintas interpretações do antropônimo:

(46) O médico Carlos Chagas (1879-1934), que há cem anos descobriu uma doença transmitida pelo barbeiro e que acabou conhecida pelo nome de mal de Chagas, é, com razão, um dos maiores cientistas brasileiros até hoje.

(http://www1.folha.uol.com.br/fsp/ilustrad/fq1505200931.htm)

Em (46), fala-se da doença descoberta pelo médico sanitarista e bacteriologista Carlos Chagas, a qual levou o seu nome. Em português, mal de Chagas e doença de Chagas correspondem a essa enfermidade e podem ser usados pelo falante sem que este conheça qualquer propriedade do portador do nome próprio. No entanto, no Quadro 1, observam-se as várias construções com o mesmo antropônimo que permitem interpretações diferenciadas:

QUADRO 1: Interpretações dos SNs com o antropônimo Carlos Chagas

\begin{tabular}{|c|c|}
\hline & GRUPO 1 \\
\hline 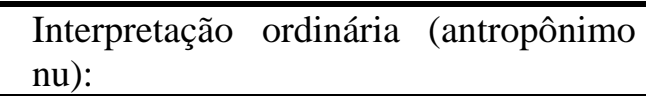 & $\begin{array}{l}\text { (47) Carlos Chagas foi diretor do Departamento } \\
\text { Nacional de Saúde Pública. }\end{array}$ \\
\hline $\begin{array}{l}\text { Antropônimo precedido por artigo } \\
\text { definido singular [Art. def. sing. + } \\
\text { Antr.] }\end{array}$ & $\begin{array}{l}\text { (48) O Carlos Chagas era filho de Mariana } \\
\text { Cândida. }\end{array}$ \\
\hline $\begin{array}{l}\text { Antropônimo precedido por artigo } \\
\text { definido plural [Art. def. pl. } \\
\text { + Antr.] }\end{array}$ & $\begin{array}{l}\text { (49) Aquela revista continha informações } \\
\text { biográficas sobre o médico Carlos Chagas e } \\
\text { sobre o jornalista Carlos Chagas. Após a } \\
\text { leitura, descobrimos que os Carlos Chagas } \\
\text { nasceram em Minas Gerais. }\end{array}$ \\
\hline $\begin{array}{l}\text { Antropônimo precedido por nome de } \\
\text { parentesco [Art. def. pl. + nome de } \\
\text { parentesco + Antr.] }\end{array}$ & $\begin{array}{l}\text { (50) Os irmãos Chagas, da mesma forma que o } \\
\text { pai, Carlos Chagas, estudaram medicina } \\
\text { também }{ }^{12} \text {. }\end{array}$ \\
\hline $\begin{array}{c}\text { Antropônimo } \\
\text { próprio } \\
\text { [o/a } \\
\text { Antr.] }\end{array}$ & $\begin{array}{l}\text { (51) O próprio Carlos Chagas preferia que a } \\
\text { doença descoberta se chamasse } \\
\text { tripanossomíase americana. }\end{array}$ \\
\hline
\end{tabular}

${ }^{12}$ Nesse caso, parece ser bem mais comum a ocorrência com sobrenomes. 


\begin{tabular}{|c|c|}
\hline $\begin{array}{l}\text { Antropônimo precedido por adjetivo } \\
\text { [Art. def. + Adj. + Antr.] }\end{array}$ & $\begin{array}{l}\text { (52) O premiado Carlos Chagas morreu em } \\
1934 .\end{array}$ \\
\hline $\begin{array}{l}\text { Antropônimo precedido por } \\
\text { possessivo [(Art. def. }+ \text { ) } \\
\text { Antr.] }\end{array}$ & $\begin{array}{l}\text { (53) Louis Pasteur, Robert Koch e o nosso } \\
\text { Carlos Chagas foram bacteriologistas } \\
\text { famosos. }\end{array}$ \\
\hline $\begin{array}{lrr}\text { Antropônimo } & \text { precedido } & \text { por } \\
\text { demonstrativo } & \text { [Art. def. }+ & \text { Adj. }+ \\
\text { Antr.] } & & \\
\end{array}$ & $\begin{array}{l}\text { (54) Esse Carlos Chagas é um orgulho para os } \\
\text { brasileiros! }\end{array}$ \\
\hline $\begin{array}{l}\text { Antropônimo precedido por tal e certo } \\
\text { [Art. def. + tal/certo + Antr.] }\end{array}$ & $\begin{array}{l}\text { (55) No início do século XX, um tal/certo } \\
\text { Carlos Chagas defendia sua tese sobre a } \\
\text { malária. }\end{array}$ \\
\hline \multicolumn{2}{|r|}{ Grupo 2} \\
\hline $\begin{array}{l}\text { A interpretação "manifestação, } \\
\text { "fase" ou "imagem” do referente } \\
\text { [Art. def. + Antr. + expansão] }\end{array}$ & $\begin{array}{l}\text { (56) O Carlos Chagas que foi para o Rio } \\
\text { estudar Medicina não era mais o mesmo } \\
\text { que havia estudado em São João del Rei. }\end{array}$ \\
\hline $\begin{array}{l}\text { A interpretação metafórica [Art. } \\
\text { ind. + Antr. + expansão] }\end{array}$ & $\begin{array}{l}\text { (57) Um Carlos Chagas do século XX deveria } \\
\text { receber muito apoio para suas pesquisas. }\end{array}$ \\
\hline A interpretação metonímica [Antr.] & $\begin{array}{l}\text { (58) Hoje meus alunos do Ensino Fundamental } \\
\text { conheceram Carlos Chagas. }\end{array}$ \\
\hline $\begin{array}{l}\text { O antropônimo como qualificativo } \\
\text { [Art. }+ \text { NC }+ \text { Antr.] }\end{array}$ & $\begin{array}{l}\text { (59) Aqueles agentes sanitários acabaram } \\
\text { desenvolvendo um espírito Carlos Chagas. }\end{array}$ \\
\hline \multicolumn{2}{|r|}{ Grupo 3} \\
\hline Referência a espaços físicos & $\begin{array}{l}\text { (60) O Hospital Carlos Chagas está localizado } \\
\text { na Rua Barão de Mauá. }\end{array}$ \\
\hline Epônimo & $\begin{array}{l}\text { (61) O mal de Chagas é transmitido por insetos } \\
\text { conhecidos por barbeiros. }\end{array}$ \\
\hline
\end{tabular}

Como é possível observar pelo quadro acima, existe uma gradativa perda de referência ao portador inicial do antropônimo. Essa gradação parte da referência ao próprio portador do nome próprio Carlos Chagas (Grupo 1), segue-se à referência de imagens, produtos ou propriedades desse portador (Grupo 2) e termina com a referência a entidades que não se identificam mais com o médico brasileiro, mas que levam o seu nome (Grupo 3).

\section{CONCLUSÃO}

Este trabalho teve como objetivo propor uma classificação semântica dos usos de antropônimos em dados de língua portuguesa escrita. A hipótese era que seria possível, por meio dessa classificação, evitar a incômoda dicotomia entre nome próprio modificado e nome próprio não modificado.

Com relação objetivo geral, a análise dos dados de língua portuguesa relevou que é possível aplicar a distinção em três grupos, com suas subdivisões. Embora os dados não tenham possibilitado identificar as mesmas construções em todos os grupos, em termos gerais, foi possível caracterizá-los mediante as propriedades semânticas dos SNs antroponímicos. Embora um corpus maior possa revelar construções não identificadas, acreditamos que os dados coletados constituam uma amostra bastante significativa daquelas que têm sido discutidas pelos trabalhos da área. 
Com respeito à hipótese, este texto mostrou uma possibilidade de classificação dos usos de antropônimos sem que se tenha de recorrer à distinção entre nomes próprios modificados e não modificados - e nem à oposição nomes próprios e empregos derivados dos nomes próprios, comentada anteriormente. Como há uma polêmica nos estudos linguísticos sobre quais seriam os nomes próprios modificados, conforme exposto no início, este trabalho evitou essa visão dicotômica analisando as ocorrências de antropônimos a partir da referência dos sintagmas que contêm o nome próprio. No final, por meio de um antropônimo específico, foi possível exemplificar a diversidade de interpretações que um SN formado por um nome próprio de pessoa, geralmente conhecida, pode receber no uso da língua.

\section{REFERÊNCIAS}

AMARAL, E. T. R. Nomes próprios: análise de antropônimos do espanhol escrito. Tese (Doutorado em Letras - Área de Língua Espanhola e Literaturas Espanhola e Hispano-Americana) - Faculdade de Filosofia, Letras e Ciências Humanas, Universidade de São Paulo, 2008.

CASTILHO, A.T. de. Demonstrativos. In: ILARI, R.; NEVES, M. H. M. (Orgs.). Gramática do português culto falado no Brasil. Campinas: UNICAMP, 2008. v. 2, p. 117-136.

FAUCONNIER, G. Espaces mentaux: aspects de la construction du sens dans les langues naturelles. Paris: Les éditions de minuit, 1984.

FERNÁNDEZ LEBORANS, M. J. El nombre propio. In: BOSQUE MUÑOZ, I.; DEMONTE BARRETO, V. (Dir.). Gramática descriptiva de la lengua española. Madrid: Espasa Calpe, 1999. v. 1, p. 77-128.

FLAUX, N. La catégorisation du nom propre. In: NOAILLY, M. (Ed.). In: Nom propre et nomination: actes du Coloque de Brest 21-24 avril 1994. Paris: Klincksieck, 1995. p. 63-73.

GARY-PRIEUR, M-N. Grammaire du nom propre. Paris: Presses Universitaires de France, 1994.

L’individu pluriel: les noms propres et le nombre. Paris: CNRS, 2001.

Où il est montré que le nom propre n'est (presque) jamais «modifié». Langue Française - noms propres: la modification, Paris: Larousse, 146, p. 53-66, 2005.

JONASSON, K. Le nom propre: constructions et interprétations. Lourain-la-Neuve: Duculot, 1994.

KLEIBER, G. Problèmes de référence: descriptions définies et noms propres. Paris: Klincksieck, 1981. 
Du nom propre nom modifié au nom propre modifié: le cas de la détermination des noms propres par l'adjectif démonstratif. Langue française: Syntaxe et sémantique des noms propres, apresentado por M.-N. Gary-Prieur, Paris, Larousse, 92, p. 104-112, déc, 1991.

Sur la définition des noms propres: une dizaine d'années après. In: NOAILLY, M. (Ed.). Nom propre et nomination: actes du Coloque de Brest 21-24 avril 1994. Paris: Klincksieck, 1995. p. 11-36.

Retour sur les noms propres standard modifiés. Linguística: Revista de Estudos Linguísticos da Universidade do Porto, 1, n. 1, p. 33-51, 2006.

LANGUE FRANÇAISE - Noms propres: la modification. Paris, Larousse, 146, juin 2005.

LEROY, S. Le nom propre en français. Paris: Ophrys, 2004.

MARTÍNEZ, J. A. La concordancia. In: BOSQUE MUÑOZ, I.; DEMONTE BARRETO, V. (Dir.). Gramática descriptiva de la lengua española. Madrid: Espasa Calpe, 1999. v. 2, p. 2695-2786.

MELHEM, S. Dicionário de epônimos (anatomia, embriologia, histologia). Taubaté: Editora da Universidade de Taubaté, 1996.

NOAILLY, M. “L’énigmatique Tombouctou”: nom propre et position de l'épithète. Langue française: Syntaxe et sémantique des noms propres, apresentado por M.-N. Gary-Prieur, Paris, Larousse, 92, p. 104-112, déc, 1991.

«Ce même Bajazet» : nom propre et principe d'identité. Lexique - Les noms propres: nature et determination, Villeneuve d'Ascq: Presses universitaires du septentrion, v. 15, p. 21-34, 2000. 